\title{
Perlindungan Hukum Potensi Indikasi Geografis Guna Meningkatkan Ekonomi Masyarakat (Studi pada Kabupaten Trenggalek)
}

\author{
Ibnu Maulana Zahida ${ }^{1}$, Sri Reski Putri ${ }^{2}$, Aditya Satrio Wicaksono ${ }^{3}$ \\ 1ProgramStudi Magister Ilmu Hukum, Fakultas Hukum, Universitas Airlangga, \\ E-mail: Ibnu7maulana@gmail.com \\ 2 ProgramStudi Magister Ilmu Hukum, Fakultas Hukum, Universitas Airlangga, \\ E-mail: Srireskiputri1604@gmail.com \\ 3 Program Studi Magister Ilmu Hukum, Fakultas Hukum, Universitas Airlangga, \\ E-mail: Adityasatrio1710@gmail.com
}

\begin{tabular}{l}
\hline Info Artikel \\
\hline Masuk:3 February 2021 \\
Diterima: 30 Juli 2021 \\
Terbit: 31 Juli 2021 \\
Keywords: \\
Economy:, Geographical \\
indication; Trenggalek \\
\\
\\
\\
Kata kunci: \\
Ekonomi; Indikasi Geografis; \\
Trenggalek \\
Corresponding Author: \\
Ibnu Maulana Zahida; E-mail : \\
Ibnu7maulana@gmail.com \\
DOI: \\
10.24843/IMHU.2021.v10.i02. \\
p09
\end{tabular}

Info Artikel

Diterima.30 Juli 2021

Keywords:

Economy:; Geographical

indication; Trenggalek

Kata kunci:

Ekonomi; Indikasi Geografis;

od

thor:

Ibnu Maulana Zahida; E-mail :
Abstract

Geographical indications give a role to the community regarding added value proposition, quality, and property to increase the competitiveness of a product. The purpose of this research is to find and develop potential Geographical Indication in the Trenggalek Regency. Finding means acquiring new knowledge, developing the meaning of expanding, and digging deeper into existing realities. The legal approach used in this research is juridical empirical. The type of research is descriptive, and data collection uses the method of literature study, and empirical legal research, the method of analysis used is qualitative. The results of a study on the legal protection of geographic indications in the Trenggalek Regency show that there are problems that the government must resolve. Because the community and government of Trenggalek Regency have not registered potential geographic indications in their area, the legal protection of potential geographical indications in Trenggalek Regency can be preventive or repressive.

\section{Abstrak}

Indikasi geografis memberikan peran terhadap masyarakat tentang adanya nilai lebih pada suatu produk yang ditawarkan, baik dari segi kualitas maupun dari segi properti yang dapat meningkatkan daya saing suatu produk. Tujuan penulisan ini adalah untuk menemukan dan mengembangkan potensi Indikasi Geografis ada kabupaten Trenggalek. Menemukan berarti memperoleh pengetahuan yang baru, mengembangkan maksudnya memperluas dan menggali lebih dalam realitas yang sudah ada. Pendekatan ilmu hukum yang digunakan dalam penelitian ini yaitu yuridis empiris, jenis penelitiannya adalah deskriptif, pengumpulan data menggunakan metode studi kepustakaan dan penelitian hukum empiris, metode analisis yang digunakan adalah kualitatif. Hasil kajian tentang perlindungan hukum indikasi geografis yang berada di Kabupaten Trenggalek menunjukkan bahwa terdapat persoalan yang harus diselesaikan pemerintah, hal tersebut dikarenakan masyarakat dan pemerintah Kabupaten Trenggalek belum mendaftarkan potensi indikasi 
geografis yang terdapat di wilayahnya. Kemudian perlindungan hukum potensi indikasi geografis di Kabupaten Trenggalek dapat dilakukan secara preventif maupun seara represif.

\section{Pendahuluan}

Indikasi Geografis merupakan salah satu bagian dari Hak Kekayaan Intelektual yang dalam dekade terakhir dikembangkan oleh beberapa negara di dunia. Indikasi Geografis adalah rambu yang di indikasikan secara Geografis untuk difungsikan sebagai produk yang memiliki asal geografis tertentu dan mempunyai kualitas (quality) atau reputasi (reputation) terkait dengan asalnya.

Indonesia telah mengesahkan Agreemention Establishing the World Trade Organization (WTO) melalui UU Nomor 7 Tahun 1994 Tentang Pengesahan Agreement Establishing The World Trade Organization (Persetujuan Pembentukan Organisasi Perdagangan Dunia) yang bertujuan "Fair Competition sebagai "open equitable, just competition which is fair as between competitor and between of his customer", 1 dalam mencapai persaingan sehat harus ada 3 (tiga) instrument hukum yang harus di tegakkan yaitu hukum anti monopoli, hukum pencegahan persaingan curang, dan hukum kekayaan intelektual. ${ }^{2}$

Salah satu agenda WTO yang terkait dengan Hukum Kekayaan Intelektual tercantum dalam Annex II adalah Agreement on Trade Related Aspect of Intellectual Property Rights including trade in Counterfeit Goods (TRIPs). Konsekuensi yuridis atas diratifikasinya perjanjian TRIP's mewajibkan Indonesia membentuk regulasi mengenai Indikasi Geografis. Indonesia berusaha membuat regulasi Indikasi Geografis diawali dikeluarkannya UU No 14 Tahun 1997 mengenai merek. Setelah dikeluarkan, namun tidak terjadi kemajuan sama sekali dalam praktikya, setelah itu UU No 14 Tahun 1997 tidak berlaku lagi, dikarenakan sudah dicabut, kemudian diganti dengan Undang-Undang Nomor 15 Tahun 2001 Tentang merek. Determinasi mengenai Indikasi Geografis dalam UU Merek pada praktiknya tidak berjalan, sebab tidak terdapat norma aplikasi determinasi pasal-pasal mengenai Indikasi Geografis dalam UU Merek, berikutnya pada tahun 2016 disahkanlah regulasi UndangUndang Nomor 20 Tahun 2016 Tentang Merek dan Indikasi Geografis (UU MIG), dengan mencabut regulasi UU Nomor 15 Tahun 2001 Tentang Merek.

Hadirnya UU MIG sebagai jawaban dari era of global trade selaras dengan perjanjian perdagangan internasional yang sebelumnya telah diratifikasi Indonesia. Partisipasi merk serta Indikasi Geografis jadi amat berarti, paling tidak dalam melindungi kompetisi upaya yang berkeadilan, pelindungan asal, dan pelindungan usaha mikro, kecil, dan menengah (UMKM). Indikasi Geografis meletakkan perlindungan kepada produk yang mengidentifikasikan dalam sesuatu area wilayah dari asal barang, dimana nama asal, mutu serta karakter benda itu amat ditetapkan oleh aspek geografi. Karakteristik mutu produk yang dilindungi harus dijaga dalam kurun waktu yang tidak ditentukan, akan menghasilkan nama asal produk, yang berikutnya membolehkan produk itu memiliki angka ekonomi tinggi.

${ }^{1}$ Cenuk Sayekti, "Competition Law Harmonization: What ASEAN Can Learn From Others?," Refleksi Hukum: Jumal Ilmu Hukum 4, no. 2 (2020): 195-216. h. 199.

${ }^{2}$ Rahmi Jened, "Konflik Yurisdiksi Dan Penegakan Hukum Kekayaan Intelektual Dalam Rangka Pasar Tunggal," Jumal Mimbar Hukum 28, no. 2 (2016): 201-14. h. 202 
Indikasi Geografis meletakkan perlindungan terhadap produk yang mengidentifikasikan kedalam sesuatu area wilayah dari asal barang, dimana nama asal, mutu, serta karakter benda itu amat ditetapkan oleh aspek geografis yang berhubungan. Karakteristik serta mutu barang yang dipelihara serta bisa dipertahankan dalam waktu durasi khusus hendak melahirkan nama asal atas barang, yang berikutnya membolehkan barang itu memiliki angka ekonomi besar.

Indonesia terdapat banyak kekayaan adat, sumber daya alam, dan produk unggulan. Seperti, ubi cilembu, salak ponggoh, Kopi Arabika, Kintamani Bali, dan lain sebagainya. Selain itu ada banyak pula produk yang dihasilkan berdasarkan kebudayaan setempat, baik berbentuk produk barang ataupun kesenian lokal. Seperti, Tenun Gringsing Bali, Mebel Ukir Jepara, Tenun Sutera Mandar dan lain sebagainya. ${ }^{3}$ Melalui proteksi Indikasi Geografis yang maksimal, diharapkan bisa terpelihara, pemberdayaan energi alam serta diharapkan bisa lebih dioptimalkan. Di samping itu, perpindahan masyarakat ke kota diharapkan dapat dihilangkan, dengan terbukanya kesempatan serta berbagai kegiatan menciptakan produk berciri khas daerah yang dilindungi dengan Indikasi Geografis akan mempunyai angka ekonomi besar di daerahnya, khususnya di Kabupaten Trenggalek. Alhasil ekonomi lokal Kabupaten Trenggalek dapat meningkat. Lebih dari itu, proteksi Indikasi Geografis menjadikan City Branding dengan memposisikan produk yang berasal dari Kabupaten Trenggalek. Sehingga meningkatkan kondisi perdagangan regional dan perdagangan global dalam rangka Asean Free Trade Agreement (AFTA), Asean and China Free Trade Agreement (ACFTA), Asean and India Free Trade Agreement (AIFTA), Asean and Korea Free Trade Agreement (AKFTA) serta Indonesia and Japan Economic Partnership Agreement (IJEPA). ${ }^{4}$

Kabupaten Trenggalek mempunyai kemampuan relatif besar dalam potensi alam yang dapat dikembangkan. Searah terdapatnya kemandirian daerah, nyaris tiap daerah dihadapkan dalam sesuatu kasus, antara lain bagaimana usaha membuat pemasukan pendapatan daerah untuk membantu kesinambungan roda pemerintahan, bagaimana menumbuhkembangkan kreatifitas masyarakat mampu melindungi kelestarian alam. Tidak hanya itu, yang lebih penting menghadapi persaingan global.

Diantara potensi Indikasi Geografis dari Kabupaten Trenggalek, berdasarkan pendapat penulis yang layak untuk dilakukan sertifikasi Indikasi Geografis adalah sektor pertanian, yaitu durian berasal dari hutan durian terbesar di dunia yang berada di 4 wilayah kecamatan antara lain; Kecamatan Watulimo, Munjungan, Kampak, dan Bendungan, Sektor perkebunan yaitu perkebunan kopi berada di lereng Gunung wilis, dan Sektor Perikanan yaitu ikan asap. Dari ke tiga (3) potensi Indikasi Geografis tersebut, pertanian kopi Wilis pada saat penelitian ini dilakukan, dikelola oleh pemerintah daerah Trenggalek, selain dari itu dikelola masyarakat.

Kabupaten Trenggalek memiliki wilayah hutan durian dengan luas mencapai 650 hektar yang dikenal sebagai hutan durian internasional (Internasional Durio Forestry)

\footnotetext{
${ }^{3}$ Rian Saputra, Adi Sulistiyono, and Emmy Latifah, "Pendaftaran Internasional Sebagai Upaya Perlindungan Indikasi Geografis Indonesia Dalam Perdagangan Global (Study Peraturan Pemerintah Nomor 22 Tahun 2018)," Jumal IUS Kajian Hukum Dan Keadilan 7, no. 2 (2019). h. 238.

4 Yuventus Effendi, "ASEAN Free Trade Agreement Implementation for Indonesian Trading Performance: A Gravity Model Approach," Buletin Ilmiah Litbang Perdagangan 8, no. 1 (2014): 1-22. h. 2 .
} 
yang telah dikembangkan menjadi kawasan desa wisata durensari. Perkebunan kopi yang berada di lereng Gunung wilis, terdapat pabrik kopi Van Dilem mulai berproduksi pada tahun 1930, terletak di desa Dompyong, kecamatan Bendungan, Trenggalek, Jawa Timur. Jenis kopi yang ditanam merupakan jenis robusta ditanam di atas $800 \mathrm{mdpl}$, proses produksi kopi di Pabrik kopi Van Dilem berbeda dari pabrik kopi lainnya. Hal tersebut membuat kopi yang di produksi di Pabrik kopi Van Dilem menjadi istimewa atau unik. Mesin pengolahan kopi yang di bangun oleh Meneer Van Dillem menggunakan tenaga air untuk mengoperasikan mesin penggiling kopi. ${ }^{5}$

Salah satu objek wisata alam andalan Kabupaten Trenggalek yaitu berada di tepi laut pantai Prigi desa Tasikmadu. Sumber daya laut di pantai Prigi telah diolah menjadi berbagai produk, antara lain merupakan produk ikan panggang, bakar, serta Ikan asap diawetkan dengan cara natural memakai metode pengasapan. Ikan yang diolah dengan metode pengasapan bisa tahan lama diakibatkan oleh sebagian aspek, antara lain; berkurangnya kandungan air ikan sampai dibawah 40 persen, terdapatnya senyawa-senyawa di dalam asam kayu yang membatasi perkembangan renik pembusuk serta terbentuknya koagulasi protein. ${ }^{6}$ Potensi ikan asap Watulimo ini menurut penulis dapat dikembangkan guna meningkatkan perekonomian masyarakat.

Adanya produk asal yang belum mendapatkan sertifikat Indikasi Geografis jangan sampai kasus kopi aceh gayo dari Nangro Aceh Darussalam akan terulang kembali, seperti perusahaan Hollad Coffe B.V. di Amsterdam Belanda dengan merek "Gayo Mountaint Coffe" didaftarkan di Merek kelas 30 untuk berbagai jenis kopi dan gula? Sehingga kasus seperti itu tidak akan terulang kembali dan akan berdampak peningkatan ekonomi pada Kabupaten Trenggalek, lantaran kekuatan ekonomi daerah mampu membuktikan dapat mengatasi goncangan perekonomian. Sekalipun menghadapi krisis moneter tahun 1998, bahkan di saat ekonomi terpuruk akibat pandemi virus covid-19 saat penelitian ini dilakukan.

Mengingat banyaknya hasil produk yang berpotensi, Indikasi Geografis masih belum memperoleh fasilitas pengembangan baik dari pemerintah pusat maupun pengembangan yang dilakukan pemerintah daerah, sebagaimana diamanatkan oleh UU MIG. Kabupaten Trenggalek tercatat sebagai kabupaten termiskin urutan ke 13, prosentase sebesar 10.98 \% dengan jumlah 76.44 jiwa pada tahun 2019.8 Banyaknya potensi produk asal Kabupaten Trenggalek, namun belum ada yang dilindungi dengan Indikasi Geografis. Setelah mendapatkan perlindungan Indikasi Geografis, diharapkan nantinya roda perekonomian yang ada di Kabupaten Trenggalek akan

\footnotetext{
${ }^{5}$ Wawancara dengan Lamiran, Kepala desa Dompyong Kecamatan Bendungan, (04 Desember 2020).

${ }^{6}$ Sanny Andjar Sari, L A Salammia, and Sri Indriani, "Penerapan Quality Function Deployment Pada Desain Mes in Pengasapan Ikan," Industri Inovatif: Jumal Teknik Industri 10, no. 1 (2020): 1-5. h. 8.

${ }^{7}$ Trias Palupi Kumianingnum, "Perlindungan Hak Ekonomi Atas Indikasi Geografis (The Economic Rights Protection For Geographical Indication)," Negara Hukum: Membangun Hukum Untuk Keadilan Dan Kesejahteraan 7, no. 1 (2017): 19-34.Trias Palupi Kumianingrum, "Pelindungan Hak Ekonomi A tas Indikasi Geografis," Negara Hukum 7, no. 1 (2016): 19-34, https $/ /$ doi.org/10.22212/jnh.v7i1.947. h. 20.

8 "BPS Provinsi Jawa Timur," accessed December 5, 2020, https://jatim.bps .go.id/statictable/2020/06/10/2091/jumlah-dan-persentase-penduduk-mis kin-diprovinsi-jawa-timur-menurut-kabupaten-kota-2017---2019.html.
} 
naik, serta kesejahteraan masyarakat Trenggalek akan tercukupi dengan usahanya sendiri. Tidak lupa, diperlukan city branding bagi Kabupaten Trenggalek.

Sebagaimana yang telah dijelaskan di atas, hal tersebut yang mendorong penulis untuk melakukan penelitian lebih lanjut mengenai bagaimana perlindungan hukum potensi Indikasi Geografis di Kabupaten Trenggalek untuk dapat meningkatkan perekonomian, bagaimana peran masyarakat dan pemerintah Kabupaten Trenggalek dalam perlindungan Indikasi Geografis, serta bagaimana menumbuhkan city branding bagi Kabupaten Trenggalek.

Dari penelitian terdahulu, penulis tidak menemukan judul yang serupa, namun menemukan beberapa penelitian yang berkaitan seperti Siti Asyfiyah "perlindungan hukum potensi indikasi geografis di kabupaten brebes guna pengembangan ekonomi masyarakat lokal", Agus Arika Eno "pendaftaran potensi indikasi geografis guna meningkatkan kesejahteraan daerah", dan Nizar Apriansyah "perlindungan indikasi geografis dalam rangka mendorong perekonomian daerah". Dalam penelitian kali ini yang membedakan dengan penelitian terdahulu adalah lokasi penelitian yang dilakukan pada Kabupaten Trenggalek dan penulis menggunakan city branding sebagai bagian dari Indikasi Geografis, hal tersebut tidak ditemukan dalam penelitian terdahulu mengenai Indikasi Geografis.

Penelitian ini pada dasarnya bertujuan untuk menemukan dan mengembangkan potensi Indikasi Geografis pada kabupaten Trenggalek. Menemukan berarti memperoleh pengetahuan yang baru, mengembangkan maksudnya memperluas dan menggali lebih dalam realitas yang sudah ada. Sedangkan tujuan penelitian hukum menurut Soerjono Soekanto, adalah untuk: Mendapatkan pengetahuan tentang gejala hukum, sehingga dapat merumuskan masalah, memperoleh pengetahuan yang lebih mendalam mengenai suatu gejala hukum, sehingga dapat merumuskan hipotesa. Tujuan penelitian juga untuk mengembangkan secara lengkap aspek-aspek hukum dari suatu keadaan, perilaku masyarakat dan perilaku kelompok. ${ }^{9}$

\section{Metode Penelitian}

Metode penelitian yang digunakan dalam jurnal ini yaitu pendekatan yang bersifat yuridis empiris. Penelitian yuridis empiris ditujukan mengenai keberlakuan hukum dan implementasi hukum normatif dalam kenyataan yang ada di masyarakat. ${ }^{10}$ Dalam penulisan ini jenis penelitian adalah deskriptif analitis, penulis menggunakan sumber data primer dari objek yang diteliti dan data sekunder sebagai landasan teoritis, dalam pengumpulan data penulis menggunakan metode studi kepustakaan dan penelitian yang ada di masyarakat (lapangan). Setelah data yang dibutuhkan terkumpul, selanjutnya mengidentifikasi permasalah untuk menemukan solusi. Metode yang digunakan berupa analisis data kualitatif.

\footnotetext{
${ }^{9}$ Kornelius Benuf and Muhamad Azhar, "Metodologi Penelitian Hukum Sebagai Instrumen Mengurai Permasalahan Hukum Kontemporer," Gema Keadilan 7, no. 1 (2020): 20-33. h. 28-39.

${ }^{10}$ S H I Jonaedi Efendi, S H Johnny Ibrahim, and M M SE, Metode Penelitian Hukum: Normatif Dan Empiris (Prenada Media, 2018).Jonaedi Efendi, Johnny Ibrahim, and SE.h. 44.
} 


\section{Hasil Penelitian dan Pembahasan}

\subsection{Perlindungan Hukum Potensi Indikasi Geografis di Kabupaten Trenggalek}

Kabupaten Trenggalek merupakan kabupaten yang berada di Provinsi Jawa Timur. Pusat pemerintahannya terletak di Kecamatan Trenggalek yang berjarak sekitar 180 kilometer dari Kota Surabaya. Kabupaten Trenggalek mempunyai wilayah seluas 1 . 205, $22 \mathrm{~km}^{2}$ yang ditempati oleh \pm 700.000 jiwa. Posisi Kabupaten Trenggalek di pantai tepi laut selatan berbatasan dengan sisi utara Kabupaten Ponorogo; sisi timur berbatasan dengan Kabupaten Tulungagung; sisi selatan berbatasan dengan Samudera Hindia; serta sisi barat berbatasan dengan Kabupaten Pacitan.11

Berdasarkan Pasal 53 UU MIG apabila hasil produk akan mendapatkan perlindungan setelah didaftarkan Indikasi Geografis tersebut kepada menteri, dikarenakan UU MIG menerapkan sistem registrasi konstitutif. 12 Registrasi konstitutif ialah membagikan proteksi kepada pendaftar awal, serta pendaftar selanjutnya tidak berhak mendapatkan proteksi hukum. Perlindungan hukum terhadap Indikasi Geografis yang berasal dari Kabupaten Trenggalek dapat diajukan melalui Menteri Hukum dan HAM lewat Dirjen Hak Kekayaan Intelektual.

Tingkat kesadaran masyarakat Indonesia dalam memahami perlindungan Indikasi Geografis tergolong sangat rendah hal tersebut dibuktikan sampai dengan bulan Maret 2020, hanya terdapat 140 Indikasi Geografis yang sudah terdaftar pada Dirjen HKI.13 Sementara terdapat ribuan potensi Indikasi geografis yang sampai saat ini masih belum terdaftar. Sebenarnya dalam hal ini, pemerintah daerah dapat mengambil peran penting yang terdapat pada Pasal 53 Ayat (3) UU MIG, bukan hanya lembaga yang mewakili masyarakat saja yang dapat mendaftarkan. Tetapi, pemerintah daerah juga dapat, mendaftarkan Indikasi Geografis. Jika pendaftaran Indikasi Geografis didaftarkan, permasalahan seperti kopi Aceh gayo tidak akan terjadi kembali. Karena, berdasarkan Pasal 21 ayat (1) UU MIG, pendaftaran merek akan ditolak apabila memiliki kecocokan ataupun kesamaan dengan Indikasi Geografis yang telah didaftarkan.

Pada potensi Indikasi Geografis produk durian IDF, kopi Wilis, dan ikan Asap Watulimo di kabupaten Trenggalek, dapat meningkatkan angka ekonomi yang lebih tinggi dan bermanfaat sebagai alat pengembangan ekonomi lokal. Namun hal tersebut membutuhkan komitmen dari para pemangku kepentingan (stake holder) dalam hal pengelolaan serta dukungan dari pemerintah daerah maupun pemerintah pusat. Searah dengan Theory Public Benefit, bahwasanya kekayaan intelektual (Indikasi Geografis) ialah sesuatu perlengkapan untuk mencapai dan meningkatkan ekonomi. Inti teori ini membenarkan terhadap proteksi atas kekayaan intelektual

\footnotetext{
${ }^{11}$ Wawancara dengan Ir. Didik Susanto, M.Si., Kepala Dinas Pertanian dan Pangan Kabupaten Trenggalek, (21 Desember 2020)

${ }^{12}$ Devica Rully Masrur, "Perlindungan Hukum Indikasi Geografis Yang Telah Didaftarkan Sebagai Merek Berdasarkan Instrumen Hukum Nasional Dan Hukum Intemasional," Lex Jumalica 15, no. 2 (2018): 200-204. h. 200.

${ }^{13}$ Smart Legal Id, "Menyelamatkan Potensi Daerah Melalui Pendaftaran Indikasi Geografis," accessed December 5, 2021, https://smartlegal.id/hki/2020/04/26/menyelamatkan-potensi-daerah-melaluipendaftaran-indikasi-geografis/.
} 
sebagai sesuatu perlengkapan dari pertumbuhan ekonomi dengan tujuan utama memperoleh sesuatu sistem perlindungan kekayaan intelektual yang efisien. ${ }^{14}$

Pada dasarnya suatu Indikasi Geografis tidak dapat digunakan secara cuma-cuma karena apabila sudah didaftarkan tidak lagi menjadi milik umum. Yang mana terkait indikasi geografis telah diatur dalam pasal 2 ayat (4) peraturan pemerintah nomor 51 tahun 2007. Dengan begitu mengakibatkan bagi pengguna Indikasi Geografis wajib mendapatkan perijinan dari pemegang hak, apabila ia akan memproduksi ataupun menjual produknya, hal ini selaras dengan Pasal 1 Angka 10 UU MIG. Apabila pemegang hak indikasi geografis telah mendaftarkannya maka ia berhak mempunyai hak khusus, sesuai dengan pasal 1 angka 7 UU MIG telah menyebutkan. Dan bagi produsen yang menggunakan indikasi geografis tersebut harus meminta izin dari pemegang hak tersebut, dalam hal ini telah disebutkan dalam Peraturan Menteri Hukum dan Hak Asasi Manusia No. 12 tahun 2019 Pasal 16 ayat (2) huruf $b$. Tidak terdapat suatu Batasan waktu dalam melindungi indikasi geografis, baik pemerintah maupun masyarakat. Telah diatur dala, pasal 61 ayat (1) UU MIG bahwa untuk melindungi Indikasi geografis dilakukan sepanjang reputasi, mutu, serta karakteristiknya terpelihara

Philipus Hadjon mengatakan bahwa perlindungan hukum terhadap masyarakat terdapat 2 macam, antara lain; Pertama, perlindungan hukum preventif melindungi masyarakat melalui diberi peluang mengajukan pendapatnya saat sebelum ketetapan pemerintah menemukan bentuk definitive yang bermaksud menjauhi terbentuknya sengketa. Kedua, merupakan perlindungan hukum represif yang bermaksud menuntaskan sengketa. ${ }^{15}$ Jika disinggungkan dengan perlindungan Indikasi Geografis sebagai berikut:

1. Preventif bertujuan untuk menghindari, mengestimasi terdapatnya pelanggaran kepada Indikasi Geografis, sehingga UU MIG membagi perlindungan hukum baik pidana maupun perdata.

2. Represif bermaksud guna menuntaskan perselisihan atau perkara, bila terdapat pelanggaran Indikasi Geografis dengan orang atau kelompok lain. Sehingga kelompok Indikasi Geografis yang terdaftar dapat berkuasa melakukan gugatan perdata atas hak yang dirugikan oleh pemakaian Indikasi Geografis.

Perlindungan preventif terhadap Indikasi Geografis durian IDF, kopi, serta ikan asap watulimo dengan metode mendaftarkannya ke Dirtjen HKI, perihal ini sesui dengan teori proteksi Hak Kekayaan Intelektual dari Robert Sherwood yang pertama; Reward Theory ataupun disebut Teori Penghargaan yang mempunyai arti mendalam berbentuk pengakuan kepada kekayaan intelektual yang sudah diperoleh oleh seseorang sebagai pencipta, inventor ataupun desainer wajib diberi apresiasi atas karya yang ia hasilkan. ${ }^{16}$ Perlindungan terhadap kemampuan Indikasi Geografis bertujuan menikmati manfaat ekonomi atas kemampuan Indikasi Geografis ialah bentuk dari apresiasi serta diakuinya oleh negara atas kesuksesan

\footnotetext{
${ }^{14}$ Desi Indah Sari, "Perlindungan Hukum Atas Label Halal Produk Pangan Menurut Undang-Undang," Repertorium: Jumal Ilmiah Hukum Kenotariatan 7, no. 1 (2018): 1-14. h. 4.

${ }^{15}$ Luthvi Febryka Nola, "Upaya Pelindungan Hukum Secara Terpadu Bagi Tenaga Kerja Indonesia (Tki)," Negara Hukum 7, no. 1 (2016): 39, https //doi.org/10.22212/jnh.v7i1.949. h. 40.

${ }^{16}$ Yurida Zakky Umami and Kholis Ro is ah, "Perlindungan Hukum Terhadap Kelapa Kopyor Sebagai Potensi Komoditas Indikasi Geografis Kabupaten Pati," LAW REFORM 11, no. 1 (2015): 113-22. h.116
} 
dalam melestarikan Indikasi Geografis. Seperti durian IDF, kopi Wilis, serta ikan asap watulimo dalam menciptakan ataupun meningkatkan produk yang berpotensi Indikasi Geografis. Penghargaan diserahkan ketika masyarakat pemilik produk melakukan pendaftaran pada Ditjen Hak Kekayaan Intelektual. Kemudian, jika produk yang berpotensi Indikasi Geografis itu memenuhi unsur-unsur Indikasi Geografis akan mendapatkan penghargaan.

Teori kedua yaitu Recovery Theory oleh Robert Sherwood menyatakan teori ini mempunyai pandangan bahwa pencipta, inventor, atau desainer yang sudah menghasilkan biaya, waktu dan tenaga dalam menciptakan sebuah karya intelektualnya wajib mendapatkan kembali apa yang sudah dikeluarkannya. ${ }^{17}$ Setelah Indikasi Geografis akan mendapatkan perlindungan hukum yang berarti pendaftar mendapatkan apa yang ia telah lakukan. Hingga setelah penelitian penulis ini lakukan pada bulan desember 2020, belum terbentuk lembaga yang meninjau lebih dalam terhadap durian IDF, kopi Wilis, serta ikan asap Watulimo. Sementara itu wadah ataupun lembaga pemerhati ini sebagai pilar dari registrasi Indikasi Geografis.

Belum adanya lembaga atau organisasi yang secara khusus memperhatikan potensi Indikasi Geografis durian IDF, kopi Wilis, serta ikan asap Watulimo. Konsekuensi belum adanya lembaga tersebut dapat mempengaruhi buku penyusunan pernyaratan Indikasi Geografis, sebab buku persyaratan mewajibkan adanya lembaga yang konsen terhadap Indikasi Geografis. Salah satu perubahan penting dalam pelaksanaan pelindungan Indikasi Geografis setelah berlakunya UU MIG 2016 adalah terdapatnya istilah baru "Dokumen Deskripsi Indikasi Geografis". DDIG Dalam Undang-Undang Merek lama Nomor 15 Tahun 2001, karena pengaturan Indikasi Geografis jauh lebih terbatas, istilah itu tidak ada. Istilah yang setara dengan DDIG adalah Buku Persyaratan Indikasi Geografis (BPIG), yang dipakai dalam PP No 51 tentang Indikasi Geografis tahun 2007.

Alasan mengubah persyaratan pendaftaran Indikasi Geografis untuk meringankan permohonan pendaftaran. Sejak pemberlakuan Peraturan Pemerintah tersebut, beratnya pembuatan buku persyaratan Indikasi Geografis, serta biaya konsultasi yang amat tinggi, telah membuat sejumlah lembaga produsen mengurungkan niatnya untuk mendaftarkan produk mereka. Hal ini tentu bukan fenomena yang layak dibiarkan. DDIG merupakan sesuatu dokumen yang muat data, informasi, mutu, serta karakter produk serta atau ataupun produk yang terpaut dengan aspek geografis dari produk tersebut. Sehingga produk tersebut dapat didaftarkan Indikasi Geografis. DDIG secara pasti mereduksi ketebalan halaman dari buku persyaratan Indikasi Geografis. Meskipun demikian, pengumpulan dan penyusunan informasi yang cukup untuk mengisi dokumen deskripsi tersebut tetap harus dilakukan. Uraian yang terdapat dalam bagian Ini bermaksud memberikan gambaran tentang bentuk-bentuk informasi yang perlu ada untuk akurasi pengisian dokumen deskripsi tersebut Materi muatan Naskah Teknis untuk kepentingan DDIG tetap memuat aspek-aspek yang cukup lengkap dari eksistensi dan seluk beluk produk yang akan dilindungi.18 Aspek-aspek tersebut meliputi:

\footnotetext{
${ }^{17}$ Muhammad Fahmi Rois and Kholis Roisah, "Perlindungan Hukum Kekayaan Intelektual Kerajinan Kuningan Tumang,” Kanun Jurnal Ilmu Hukum 20, no. 3 (2018): 401-19. h. 407

${ }^{18}$ Ahmad M.R and Miranda R.A.P, Hukum Kekayaan Intelektual Indikasi Geografis Dan Kekayaan Tradisi Dalam Teori Dan Praktik (Bandung: PT. Refika Aditama, 2019). h. 33
} 
a. Lembaga pengusul dan pemegang hak Indikasi Geografis.

Guna melindungi Durian IDF, Kopi Wilis, dan Ikan Asap Watulimo dalam sistem hukum Kekayaan Intelektual Indikasi Geografis di Indonesia, pendaftaran merupakan kemestian karena stelsel pelindungannya yang bersifat konsititutif. Berdasarkan Pasal 53 Ayat (3) Undang-Undang Merek dan Indikasi Geografis 2016, pihak yang dapat menjadi pemohon pendaftaran Indikasi Geografis adalah lembaga yang mewakili masyarakat di wilayah budidaya atau pembuatan produk, atau pemerintah daerah yang berwenang di wilayah tersebut. Durian IDF, kopi Wilis, dan Ikan Asap Watulimo dapat diusulkan untuk menjadi Indikasi Geografis oleh Masyarakat Pelindung Indikasi Geografis (MPIG) atas persetujuan atau dukungan dari masyarakat Trenggalek, dan/atau oleh Pemerintah Daerah Provinsi Jawa Timur atas usul dari Pemerintah Daerah Kabupaten Trenggalek.

b. Produk atau objek yang akan dilindungi.

Durian IDF, Kopi Wilis, dan Ikan Asap Watulimo dapat dikategorikan sebagai produk potensi Indikasi Geografis karena kelekatannya dengan faktor alam dan atau faktor manusia.

c. Karakteristik, kualitas, dan reputasi produk.

Berdasarkan dari pengamatan lapangan dan wawancara dengan kepala dinas pertanian dan pangan kabupaten Trenggalek. Penulis mengambil kesimpulan bahwa karakter dari durian IDF yang khas dibandingkan durian dari daerah lain seperti duri antar juring berimpitan, dan kulit buahnya sangat tipis sehingga mudah dibuka, volume panen durian ini dapat mencapai 15 ribu ton pertahun. Kopi Wilis berasal dari bulir kopi robusta didapat dari pemberdayaan orang tani lokal Boto Putih Dompyong, ditanam pada ketinggian 800 mdpl. Setelah itu serbuk kopi Hijau tua diolah dengan cara alami buat memperoleh rasa khas pegunungan. Ikan asap Watulimo dioleh dari Ikan yang fresh, karena itu rasanya sedang amat enak, hendak namun sebab fresh ikan ini kilat memburuk bila tidak kilat dimasukan mesin penyejuk ataupun dimasak. Karena ikan yang akan diasap umumnya langsung dilakukan pengasapan tanpa terdapatnya pengawetan terlebih dahulu. ${ }^{19}$

d. Peta Wilayah Penghasil Produk

Berikut penampang Kabupaten Trenggalek yang merupakan wilayah asal durian IDF, kopi Wilis, dan ikan asap Watulimo;

19 Wawancara dengan Ir. Didik Susanto, M.Si., Kepala Dinas Pertanian dan Pangan Kabupaten Trenggalek, (21 Desember 2020) 


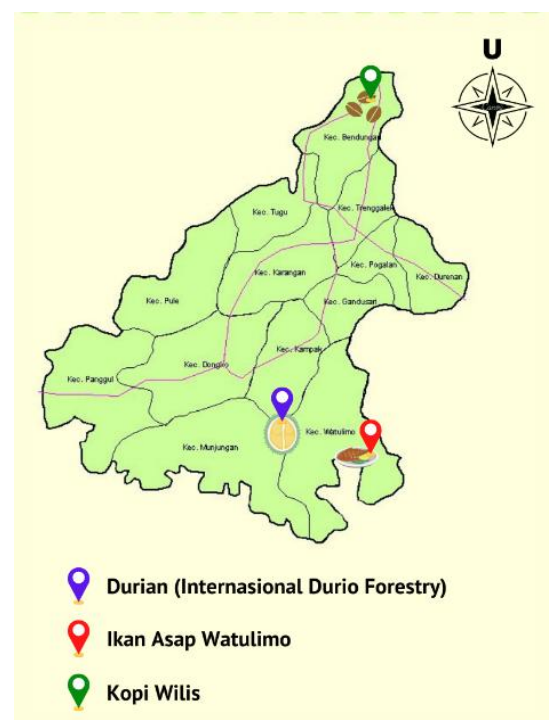

Gambar 1 Peta Potensi Indikasi Geografis di Kabupaten Trenggalek (2020)

e. Pemasaran Produk

Strategi pemasaran durian IDF, kopi Wilis, dan ikan asap Watulimo masih bersifat sporadis dan tidak sistematis. Kemudian, pemberdayaan ekonomis hanya dipelopori oleh masyarakat secara individual..

f. Pengawasan Kualitas

Pengawasan dan pembinaan dilakukan untuk menjamin bahwa sebagai produk, kualitas, dan keamanan durian IDF, kopi Wilis, dan ikan asap Watulimo tetap konsisten dengan standar mutu yang telah disepakati oleh seluruh anggota pemegang hak dan dituangkan dalam Dokumen Deskripsi Indikasi Geografis. Pengawasan dapat dilakukan dengan cara eksternal dan internal. Pengawasan eksternal dilakukan oleh konsumen, lembaga swadaya masyarakat, media, serta Tim Ahli Indikasi Geografis pada Kementerian Hukum dan Hak Asasi Manusia. Pengawasan internal dilakukan oleh komunitas pemegang Indikasi Geografis seperti masyarakat pelindung indikasi geografis (MPIG).

Apabila Durian IDF, Kopi Wilis, dan Ikan Asap Watulimo telah memenuhi DDIG dan didaftarkan sebagai Indikasi Geografis. Masyarakat pemilik Indikasi Geografis durian IDF, kopi Wilis, serta Ikan Asap Watulimo akan memperoleh sertifikat Indikasi Geografis. Setelah memperoleh sertifikat Indikasi Geografis, dapat dipergunakan untuk meningkatkan pemasaran durian IDF, Kopi Wilis, serta Ikan Asap Watulimo, sebab konsumen tidak akan meragukan dalam hal mutu produk yang sudah memperoleh sertifikat Indikasi Geografis. Pembeli akan membeli dengan harga mahal sekalipun. Tidak hanya itu, bisa pula menaikkan penjualan produk.

Robert. Sherwood kemudian menyatakan dalam teorinya yang ketiga, searah dengan kedua teori di atas yaitu Incentive Theory, mempunyai arti bahwasannya stimulus perlu diserahkan dalam memperjuangkan terpacunya kegiatan-kegiatan 
penelitian yang bermanfaat. 20 Penulis mencoba mengemukakan profit dari perlindungan Indikasi Geografis yang hendak diterima bagi petani durian IDF, kopi Wilis, serta pengolah ikan asap Watulimo sebagai berikut;

1) Meningkatkan profesionalisme petani durian IDF, kopi Wilis, serta pengolah ikan asap Watulimo (karena disyaratkan adanya dokumen deskripsi Indikasi Geografis secara spesifik untuk menjamin kualitas).

2) Meningkatkan dan memelihara produk Indikasi Geografis serta memperkuat daya saing petani durian IDF, kopi Wilis, serta pengolah ikan asap Watulimo.

3) Memperkuat hak petani durian IDF, kopi Wilis, serta pengolah ikan asap Watulimo melalui lembaga produk Indikasi Geografis.

4) Menggerakkan pemerataan ekonomi terhadap petani durian IDF, kopi Wilis, serta pengolah ikan asap Watulimo.

5) Menumbuhkan bidang usaha yang lebih banyak bagi para petani durian IDF, kopi Wilis, serta pengolah ikan asap Watulimo.

Hakikat dari ketiga teori yang sudah dipaparkan mempunyai visi yang serupa, berbentuk apresiasi pada pencipta ataupun inventor maupun desainer Indikasi Geografis. Berdasarkan penelitian ini, kepada para petani durian IDF, kopi Wilis, serta pengolah ikan asap Watulimo dilakukan perlindungan terhadap produk yang dihasilkan amat dibutuhkan untuk mengestimasi terdapatnya ketidak jujuran oleh pihak yang disinyalir tidak baik, karena Indikasi Goegrafis memberikan manfaat perekonomian kepada produsen Indikasi Geografis.

Teori yang keempat dari Robert Sherwood ialah Risk Theory yang menyatakan bahwa Hak Kekayaan Intelektual merupakan sesuatu penelitian yang memiliki risiko, sehingga membolehkan orang lain terlebih dulu menciptakan metode ataupun memperbaikinya, ${ }^{21}$ dengan begitu hal yang wajar apabila membagikan perlindungan hukum kepada usaha ataupun aktivitas yang memiliki resiko tersebut, sehingga potensi Indikasi Geografis perlu mendapatkan perlindungan hukum dengan prosedur sertifikasi. Pada saat penelitian dikerjakan oleh penulis, potensi Indikasi Geografis durian IDF, kopi Wilis, serta ikan asap Watulimo belum didaftarkan. Bila sesuatu hari potensi Indikasi Geografis durian IDF, kopi Wiis, serta ikan asap Watulimo yang belum didaftarkan oleh warga Trenggalek, ternyata sudah dipakai oleh pihak lain dengan cara tanpa hak, tidak dapat melakukan tindakan hukum, seperti tercantum pada Pasal 66 UU MIG. Maka, untuk itu wajib mengajukan pendaftaran Indikasi Geografis di Ditjen Hak Kekakyaan Intelektual guna memperoleh kejelasan perlindungan hukum.

Teori terakhir dari Robert Sherwood adalah Economic Growth Stimulus Theory, teori ini membenarkan bahwa perlindungan atas Hak Kekayaan Intelektual merupakan suatu bagian dari pembangunan ekonomi, berbentuk totalitas dibangunnya sesuatu sistem perlindungan atas Hak Kekayaan Intelektual yang efisien. ${ }^{22}$ Teori ini relevan

\footnotetext{
${ }^{20}$ Yoga Mahardhita and Ahmad Yakub Sukro, "Perlindungan Hukum Hak Kekayaan Intelektual Melalui Mekanisme 'Cross Border Measure,"” QISTIE 11, no. 1 (2018). h. 94

${ }^{21}$ Rois and Rois ah, "Perlindungan Hukum Kekayaan Intelektual Kerajinan Kuningan Tumang." h. 407 22 Ibid.
} 
untuk dijadikan dasar perlindungan Hak Kekayaan Intelektual dikala persaingan di pasar bebas. Konsekuensi dari pengadopsian perjanjian internasional seperti World Trade Organization mewajibkan Indonesia mempunyai regulasi perlindungan Hak Kekayaan Intelektual yang dapat mencukupi perdagangan ekonomi nasional ataupun global.

Berdasarkan implementasinya, dapat diketahui bahwasannya perlindungan Indikasi Geografis saat ini masih sedikit. Paling tidak, perlu disosialisasikan mengenai Indikasi Geografis terhadap para petani durian IDF, kopi Wilis, serta pengolah ikan asap Watulimo di Kabupaten Trenggalek. Dengan demikian, banyak manfaat yang bisa diperoleh, searah dengan esensi dari Hak Kekayaan Intelektual antara lain; Pertama "kesamarataan", maksudnya membagikan hak pada masyarakat, berlaku seperti pemilik Indikasi Geografis mendapatkan manfaat keuntungan, serta memperoleh pertimbangan yang baik. Kedua "ekonomi", untuk bisa menikmati profit ekonomi, dalam hal ini para petani durian IDF, kopi Wilis, dan pengolah ikan asap Watulimo. Ketiga "kultur", ialah perlindungan Indikasi Geografis durian IDF, kopi Wilis, serta pengolah ikan asap Watulimo ini akan meningkatkan derajat hidup, peradaban, serta derajat masyarakat di Kabupaten Trenggalek, yang terakhir merupakan "Sosial", memiliki sebagai maksud hak-hak yang diserahkan oleh negara ditujukan sebagai kebutuhan warga negaranya.

\subsection{Peran Masyarakat dan Pemerintah Daerah Kabupaten Trenggalek dalam melindungi potensi Indikasi Geografis}

Berdasarkan ketentuan UU MIG yang telah disampaikan sebelumnya, pemberian sertifikat (pelindungan) Indikasi Geografis dapat dimohonkan oleh 2 pihak, yaitu; Pertama, lembaga di area geografis, secara khusus mengusahakan sesuatu benda serta atau ataupun produk berbentuk: sumber daya alam; produk kerajinan tangan; ataupun hasil pabrik. Kedua, Pemerintah daerah provinsi ataupun kabupaten atau kota.

Kedua pemohon di atas, dapat menjadi pemohon potensi Indikasi Georgrafis di Kabupaten Trenggalek. Namun kedua pemohon tersebut belum bisa dijalankan, dikarenakan ada dua faktor:

1) Masih rendahnya tingkat pendidikan masyarakat Trenggalek

2) Pemahaman mengenai urgensi dari Indikasi Geografis oleh masyarakat Trenggalek masih rendah

3) Belum ada atensi dari praktisi Indikasi Geografis di Kabupaten Trenggalek

Dalam perlindungan potensi Indikasi Geografis, peran masyarakat Trenggalek hanya sampai saat ini pembentukan pengelompokan produk unggulan. Kemudian peran dari pemerintah Kabupaten Trenggalek, membentuk kelompok tani, UMKM, serta koperasi. Sehingga, belum adanya sosialisasi tentang Indikasi Geografis di Kabupaten Trenggalek disinyalir mempengaruhi tingkat kesadaran masyarakat terhadap upaya perlindungan hukum potensi Ind ikasi Geografis. Hingga pada saat penelitian ini dilakukan, Kabupaten Trenggalek belum memiliki masyarakat pemerhati Indikasi Geografis, seharusnya pemerintah Kabupaten Trenggalek menginisiasi terbentuknya masyarakat pelindung indikasi geografis yang berguna meningkatkan daya saing suatu produk. 
Seperti yang sudah dipaparkan di atas, Hak Kekayaan Intelektual di Indonesia merupakan konsep yang sebelumnya hasil ratifikasi dari perjanjian TRIP's. Hak Kekayaan Intelektual, mulanya dari budaya barat yang lebih menekankan pada masing-masing individu. ${ }^{23}$ Berbeda dengan Indonesia yang lebih mengutamakan solidaritas dan persaudaraan. Perlindungan Indikasi Geografis perlu lebih banyak menyentuh masyarakat petani durian IDF, kopi Wilis, dan pengolah ikan asap Watulimo. Dikarenakan Indikasi Geografis melindungi potensi hasil-hasil pertanian durian IDF, kopi Wilis serta pengolahan ikan asap Watulimo yang mempunyai kualitas dan karakteristik. Kehadiran UU MIG harus disambut positif oleh masyarakat Trenggalek guna meningkatkan asset daerahnya. Perlindungan Indikasi Geografis tidak mempunyai jangka waktu, tetapi karakteristik serta mutu Indikasi Geografis itu senantiasa terpelihara, dengan begitu tidak hanya memperoleh peningkatan ekonomi, pelindungan hukum Indikasi Geografis pula berperan bagaikan alat untuk melindungi kelestarian alam serta lingkungan.

Penelitian lapangan mengenai peran masyarakat Trenggalek dalam melindungi Indikasi Geografis, penulis beranggapan bahwa masyarakat Trenggalek belum mempunyai pemahaman hukum mengenai manfaat Indikasi Geografis di Trenggalek. Oleh sebab itu supaya potensi-potensi Indikasi Geografis yang terdapat di wilayah Trenggalek dapat bertumbuh dengan baik serta memperoleh perlindungan hukum, diperlukan pemberdayaan sumber daya manusianya, dan pengembangan kelembagaan ditingkatkan lagi.

Kepedulian pemerintah Kabupaten Trenggalek terhadap produk-produk khas daerah Kabupaten Trenggalek seyogyanya ditunjukkan melalui tindakan pemerintah, dalam hal ini Dinas Pertanian Kabupaten Trenggalek maupun praktisi Indikasi Geografis melakukan sosialisasi penyuluhan Hak Kekayaan Intelektual terkait Indikasi Geografis kelembaga gabungan kelompok tani penghasil durian IDF, kopi Wilis, beserta pengolah ikan asap Watulimo. Kebijakan tersebut merupakan hal baru dan benar mengenalkan Indikasi Geografis kepada masyarakat. Implikasi kebijakan sosialisasi meningkatkan pemahaman terhadap masyarakat Trenggalek, selain itu sosialisasi berfungsi penghubung atas keberhasilan rezim Indikasi Geografis, tanpa adanya sosialisasi mengakibatkan kurangnya pemahaman, sebab masyarakat tidak mengetahui pentingnya perlindungan Indikasi Geografis terhadap hasil produk masyarakat. Pemerintah Kabupaten Trenggalek bertindak lebih terhadap para petani durian IDF, kopi Wilis, beserta pengolah ikan asap Watulimo agar mendapatkan keuntungan ekonomi yang lebih atas hasil usaha mereka dan memperoleh perlindungan hukum.

Demikian kenyataannya seperti yang sudah diulas di atas bahwa tingkat kesadaran hukum masyarakat Kabupaten Trenggalek masih sangat rendah. Perlindungan Indikasi Geografis akan sulit terwujud jika pemahaman masyarakat masih rendah. Oleh karenanya perlu ditingkatkan kesadaran hukum masyarakat yang masih rendah terkait dengan pemahaman perlindungan Indikasi Geografis, pemerintah Kabupaten Trenggalek berupaya melakukan pendampingan selama proses berlangsung, Setelah didaftarkan pemerintah Kabupaten Trenggalek juga mewujudkan petani durian IDF, kopi Wilis, beserta pengolah ikan asap Watulimo

\footnotetext{
${ }^{23}$ Dewa Ayu Dwi Indah Cahyanti Badung, "Transformasi Trips Agreement Terhadap Pasal 5 Ayat 1 Undang-Undang Nomor 31 Tahun 2000 Tentang Desain Industri,” Acta Comitas: Jurnal Hukum Kenotariatan 4, no. 1 (2019). h. 68
} 
dengan meningkatkan harga komuditas sebagai penghasil produk Indikasi Geografis di Kabupaten Trenggalek.

\subsection{Indikasi Geografis sebagai Pencitraan (City Branding) Kabupaten Trenggalek}

Dahulu, City Branding atau citra branding dari Kabupaten Trenggalek ialah sebagai kota gaplek, hal ini dikarenakan sebagai daerah penghasil gaplek. Tetapi seiring berkembangnya waktu masyarakat telah mengalami transformasi menuju era konseptual atau copcentual age, yaitu suatu era ketika kreativitas menjadi faktor paling penting yang menggerakkan roda ekonomi. ${ }^{24}$. Maka untuk itu perlu City Branding baru.

Era konseptual membawa perkembangan ekonomi dunia menuju ekonomi berbasis pengetahuan (knowledge based economy), yakni ketika aktivitas ekonomi didominasi oleh aktivitas peningkatan nilai tambah dan nilai jual produk. Di sisi lain, era globalisasi telah membawa produsen, baik di tingkat perseorangan, regional, maupun nasional, ke dalam persaingan yang mengandalkan kemampuan menarik perhatian, membangun pengaruh, memanfaatkan pangsa pasar, bisnis dan investasi serta kreativitas dalam menghasilkan produk yang kreatif. Kreativitas produk dapat tercipta dari elemen-elemen yang terkait dengan produk tersebut. Contoh dari elemen-elemen tersebut adalah: Indikasi Geografis durian IDF, kopi Wilis dan ikan asap Watulimo dari Trenggalek. Terkait metode dalam produksi, karakteristik produk, dan produsen penghasil produk. Kreativitas produk menjadi penting dalam kaitannya dengan penciptaan identitas produk atau branding. Pada penciptaan produk branding inilah Indikasi Geografis memegang peran sentral dalam era konseptual.

Perlindungan Indikasi Geografis di Indonesia diberikan porsi lebih dalam UU MIG. Pada sejumlah produk yang tidak dapat dilepaskan dari daerah asal, faktor geografis berperan besar dalam menciptakan keunikan produk tersebut. Jika dipadu dengan kreativitas dalam metode produksi, distribusi, dan pemasaran, keunikan yang berasal dari faktor geografis tersebut dapat meningkatkan nilai tambah serta nilai jual suatu produk secara signifikan. Sebaliknya, kualitas suatu produk yang laris terjual dengan mengangkat keunikan daerah, dapat memberikan nilai tambah terhadap daerah tersebut. Proses simbiosis mutualistis antara suatu produk dengan daerah asal itulah yang dapat membentuk pencitraan kota (city branding) atau pencitraan daerah (regional branding).

Pencitraan kota adalah proses untuk membentuk citra suatu kota sehingga identitas kota dan nilai-nilai khusus dari kota tersebut dapat lebih mudah dikomunikasikan pada target pasar. Pencitraan kota lazim menggunakan kalimat posisi-diri (positioning), slogan, ikon pameran, dan berbagai media lainnya. Pencitraan kota bertujuan agar kota tersebut lebih dikenal secara luas (high awareness) ${ }^{25}$ dan memiliki daya tarik yang tinggi bagi masyarakat luar.

\footnotetext{
${ }^{24}$ M.R and R.A.P, Hukum Kekayaan Intelektual Indikasi Geografis Dan Kekayaan Tradisi Dalam Teori Dan Praktik. h. 68.

${ }^{25}$ Faisal Arif Rahman, Indra Wijayanto NA, and Jasmine Marva Silmina, "Aspek Hukum Regional Branding Dalam Undangundang Nomor 15 Tahun 2001 Tentang Merek Dan Undangundang Nomor
} 
Produk Indikasi Geografis memiliki potensi besar untuk berperanan sebagai katalisator pencitraan Kabupaten Trenggalek. Selain itu, Indikasi Geografis juga dapat memicu pertumbuhan ekonomi kawasan Kabupaten Trenggalek. Sebagai suatu konsep, perlindungan produk Indikasi Geografis telah dipraktikkan untuk mencegah informasi yang menyesatkan mengenai asal suatu produk. Indikasi Geografis juga dipergunakan untuk melindungi hak-hak penghasil produk yang tinggal di wilayah produk Indikasi Geografis melalui penggunaan indikasi atau nama geografis yang menunjukkan asal produk. ${ }^{26}$ Hal-hal inilah yang membuat Indikasi Geografis amat bernilai bagi Kabupaten Trenggalek.

Kualitas unik suatu produk Indikasi Geografis telah terbukti menjadi faktor penentu dalam perdagangan. Menurut survei yang dilakukan di wilayah Uni Eropa, 40\% konsumen bersedia membayar harga 10\% lebih tinggi bagi produk asli daerah dengan kualitas premium. ${ }^{27}$ Pelindungan Indikasi Geografis juga telah terbukti dapat meningkatkan pertambahan nilai pada kekayaan alam, keterampilan, inovasi, dan kreativitas masyarakat lokal suatu daerah. Pertambahan nilai tersebutlah yang menguatkan daya pembeda bagi produk yang dihasilkan. ${ }^{28}$ Pertambahan nilai ini disebut sebagai signifikansi sekunder dari Indikasi Geografis; dari suatu indikasi yang hanya bernilai deskriptif menjadi indikasi yang berkesan khusus di benak konsumennya sehingga memiliki daya pembeda yang kuat.

Posisi Indikasi Geografis yang senantiasa mengakar di dalam daerah dan masyarakatnya menjadikannya sebagai kekayaan milik bersama. Dalam tataran domain publik atau kepemilikan umum, kekayaan milik bersama menjadi rawan terhadap eksploitasi dan pelanggaran. Dalam konteks ini, pelindungan terbaik terhadap kekayaan milik bersama seyogianya berbasis kepemilikan komunitas (communityownership). Kepemilikan komunitas ini menuntut adanya sinergi antara tindakan pemerintah dan partisipasi komunitas untuk menghasilkan suatu sistem pelindungan yang bukan hanya melindungi, melainkan juga produktif terhadap upaya penambahan nilai produk dan pencitraan bagi Kabupaten Trenggalek.

\section{Kesimpulan}

Potensi Indikasi Geografis yang terdapat di Kabupaten Trenggalek, belum mendapatkan perhatian serius baik dari pemerintah pusat, pemerintah daerah maupun masyarakat Trenggalek sendiri. Adanya Undang-undang nomor 20 tahun 2016 tentang Merek dan Indikasi Geografis mengamanatkan untuk dilakukan pemetaan dan inventarisasi terhadap produk potensi Indikasi Geografis yang kemudian di akomodasi oleh dinas pertanian kabupaten Trenggalek, sehingga potensi Indikasi Geografis seperti durian IDF, kopi Wilis, serta ikan asap Watulimo akan didaftar untuk memperoleh sertifikat Indikasi Geografis. Dalam hal ini

28 Tahun 2014 Tentang Hak Cipta (Studi Kasus Jogja Istimewa Sebagai Brand Daerah Istimewa YOGYAKARTA)," Jumal Penelitian Hukum-Fakultas Hukum Universitas Gadjah Mada 2, no. 3 (2015): 178-207. h. 179.

${ }^{26}$ M.R and R.A.P, Hukum Kekayaan Intelektual Indikasi Geografis Dan Kekayaan Tradisi Dalam Teori Dan Praktik. h. 70.

27 Ibid.

${ }^{28}$ G Felix, A., \& Alexandra, "Geographicol Indicotions Beyond Wines Ond Sprits: A Roadmap for a Better Protection for Geographic Indications in the WTO TRIPS Agreemen," The Journal of Wo Intellectual Property. 5 (2002). h. 865 
masyarakat serta pemerintah Kabupaten Trenggalek belum melakukan pendaftaran potensi Indikasi Geografis, mengacu pada Undang-Undang MIG mengenai perlindungan hukum potensi Indikasi Geografis dapat dilakukan dengan cara Preventif dan Represif.

Peran masyarakat dan pemerintah Kabupaten Trenggalek dalam melindungi potensi Indikasi Geografis bertujuan membentuk produk unggulan yang memiliki daya saing, tetapi belum dilakukannya penyuluhan mengenai Indikasi Geografis disinyalir sebagai salah satu faktor penghambat dalam melakukan perlindungan hukum terhadap potensi Indikasi Geografis yang berada di kawasan Kabupaten Trenggalek.

Perlindungan Indikasi Geografis sebagai city branding Kabupaten Trenggalek yang pada semula city branding sebagai kota gaplek, perlu mendapatkan identitas baru yang sesuai dengan era konseptual. Sehingga nantinya Kabupaten Trenggalek dapat dicitrakan khusus dan dapat lebih mudah dikomunikasikan pada target pasar melalui perlindungan hukum Indikasi Geografis.

\section{Ucapan terima Kasih}

Ucapan terima kasih kami sampaikan kepada:

○ Bapak Haris Yudhianto, S.H., M.H. (Ketua DPC PERADI Trenggalek)

- Bapak H. Mochamad Nur Arifin (Bupati Trenggalek)

- Bapak Ir. Didik Susanto, M.Si. (Kepala Dinas Pertanian Trenggalek)

- Bapak Lamiran (Kepala desa Dompyong)

\section{Daftar Pustaka}

\section{Buku}

Jonaedi Efendi, S H I, S H Johnny Ibrahim, and M M SE. Metode Penelitian Hukum: Normatif Dan Empiris. Prenada Media, 2018.

M.R, Ahmad, and Miranda R.A.P. Hukum Kekayaan Intelektual Indikasi Geografis Dan Kekayaan Tradisi Dalam Teori Dan Praktik. Bandung: PT. Refika Aditama, 2019.

\section{Jurnal}

Badung, Dewa Ayu Dwi Indah Cahyanti. "Transformasi Trips Agreement Terhadap Pasal 5 Ayat 1 Undang-Undang Nomor 31 Tahun 2000 Tentang Desain Industri." Acta Comitas: Jurnal Hukum Kenotariatan 4, no. 1 (2019).

Benuf, Kornelius, and Muhamad Azhar. "Metodologi Penelitian Hukum Sebagai Instrumen Mengurai Permasalahan Hukum Kontemporer." Gema Keadilan 7, no. 1 (2020): 20-33.

Effendi, Yuventus. "ASEAN Free Trade Agreement Implementation for Indonesian Trading Performance: A Gravity Model Approach." Buletin Ilmiah Litbang Perdagangan 8, no. 1 (2014): 1-22.

Felix, A., \& Alexandra, G. "Geographicol Indicotions Beyond Wines Ond Sprits: A Roadmap for a Better Protection for Geographic Indications in the WTO TRIPS Agreemen." The Journal of Wo Intellectual Property. 5 (2002).

Jened, Rahmi. "Konflik Yurisdiksi Dan Penegakan Hukum Kekayaan Intelektual Dalam Rangka Pasar Tunggal." Jurnal Mimbar Hukum 28, no. 2 (2016): 201-14.

Kurnianingrum, Trias Palupi. "Pelindungan Hak Ekonomi Atas Indikasi Geografis." Negara Hukum 7, no. 1 (2016): 19-34. https:// doi.org/10.22212/jnh.v7i1.947. 
- - -. "Perlindungan Hak Ekonomi Atas Indikasi Geografis (The Economic Rights Protection For Geographical Indication)." Negara Hukum: Membangun Hukum Untuk Keadilan Dan Kesejahteraan 7, no. 1 (2017): 19-34.

Mahardhita, Yoga, and Ahmad Yakub Sukro. "Perlindungan Hukum Hak Kekayaan Intelektual Melalui Mekanisme 'Cross Border Measure.'” QISTIE 11, no. 1 (2018).

Masrur, Devica Rully. "Perlindungan Hukum Indikasi Geografis Yang Telah Didaftarkan Sebagai Merek Berdasarkan Instrumen Hukum Nasional Dan Hukum Internasional." Lex Jurnalica 15, no. 2 (2018): 200-204.

Nola, Luthvi Febryka. "Upaya Pelindungan Hukum Secara Terpadu Bagi Tenaga Kerja Indonesia (Tki)." Negara Hukum 7, no. 1 (2016): 39. https://doi.org/10.22212/jnh.v7i1.949.

Rahman, Faisal Arif, Indra Wijayanto NA, and Jasmine Marva Silmina. "Aspek Hukum Regional Branding Dalam Undangundang Nomor 15 Tahun 2001 Tentang Merek Dan Undangundang Nomor 28 Tahun 2014 Tentang Hak Cipta (Studi Kasus Jogja Istimewa Sebagai Brand Daerah Istimewa YOGYAKARTA)." Jurnal Penelitian Hukum-Fakultas Hukum Universitas Gadjah Mada 2, no. 3 (2015): 178-207.

Rois, Muhammad Fahmi, and Kholis Roisah. "Perlindungan Hukum Kekayaan Intelektual Kerajinan Kuningan Tumang." Kanun Jurnal Ilmu Hukum 20, no. 3 (2018): 401-19.

Saputra, Rian, Adi Sulistiyono, and Emmy Latifah. "Pendaftaran Internasional Sebagai Upaya Perlindungan Indikasi Geografis Indonesia Dalam Perdagangan Global (Study Peraturan Pemerintah Nomor 22 Tahun 2018)." Jurnal IUS Kajian Hukum Dan Keadilan 7, no. 2 (2019).

Sari, Desi Indah. "Perlindungan Hukum Atas Label Halal Produk Pangan Menurut Undang-Undang." Repertorium: Jurnal Ilmiah Hukum Kenotariatan 7, no. 1 (2018): 114.

Sari, Sanny Andjar, L A Salammia, and Sri Indriani. "Penerapan Quality Function Deployment Pada Desain Mesin Pengasapan Ikan." Industri Inovatif: Jurnal Teknik Industri 10, no. 1 (2020): 1-5.

Sayekti, Cenuk. "Competition Law Harmonization: What ASEAN Can Learn From Others?" Refleksi Hukum: Jumal Ilmu Hukum 4, no. 2 (2020): 195-216.

Umami, Yurida Zakky, and Kholis Roisah. "Perlindungan Hukum Terhadap Kelapa Kopyor Sebagai Potensi Komoditas Indikasi Geografis Kabupaten Pati." LAW REFORM11, no. 1 (2015): 113-22.

\section{Website}

“BPS Provinsi Jawa Timur." Accessed December 5, 2020. https://jatim.bps.go.id/statictable/2020/06/10/2091/jumlah-dan-persentasependuduk-miskin-di-provinsi-jawa-timur-menurut-kabupaten-kota-2017--2019.html.

Id, Smart Legal. "Menyelamatkan Potensi Daerah Melalui Pendaftaran Indikasi Geografis." Accessed December 5, 2021. https://smartlegal.id/hki/2020/04/26/menyelamatkan-potensi-daerah-melaluipendaftaran-indikasi-geografis/.

\section{Peraturan Perundang-undangan}

Undang-Undang Nomor 14 Tahun 1997 Tentang merek

Undang-undang Nomor 15 Tahun 2001 Tentang Merek 
Undang-Undang Nomor 20 Tahun 2016 Tentang Merek dan Indikasi Geografis Peraturan Pemerintah Nomor 51 Tahun 2007 mengenai Indikasi Geografis

Peraturan Menteri Hukum dan Hak Asasi Manusia No. 12 tahun 2019 Tentang Indikasi Geografis

\section{Wawancara}

Ir. Didik Susanto, M.Si., Kepala Dinas Pertanian dan Pangan Kabupaten Trenggalek, (21 Desember 2020)

Lamiran, Kepala desa Dompyong Kecamatan Bendungan, (04 Desember 2020) 